\title{
Multimedia Based Learning in the Basic Lessons of Electricity and Electronics to Improve SMK Student Competency
}

\author{
Toto Tohir \\ Universitas Islam Nusantara, Bandung, Indonesia \\ Corresponding author email: toto.tohir@polban.ac.id \\ Iim Wasliman \\ Universitas Islam Nusantara, Bandung, Indonesia \\ Yosal Iriantara \\ Universitas Islam Nusantara, Bandung, Indonesia \\ Supyan Sauri \\ Universitas Islam Nusantara, Bandung, Indonesia
}

\begin{abstract}
Management of education quality refers to the National Education Standards. The purpose of this study was to determine: (1. Multimedia learning planning to improve student competence (2) Organizing multimedia learning to improve student competence (3) Implementing multimedia learning to improve student competence (4) Evaluating multimedia learning to improve student competence (5) Multimedia learning outcomes to improve student competence (6) Inhibiting factors for multimedia learning in increasing student competence Qualitative descriptive methods to describe phenomena that occur realistically Data collection techniques (1) Interview (2) Observation (3). Documentation The conclusion of the study shows that the two SMKN schools have not been optimal in terms of planning, organizing, implementing, evaluating, and multimedia learning outcomes to improve student competence in basic electricity and electronics subjects. The principal fully supports all multimedia equipment facilities and requires subject teachers to use multimedia as a learning medium.
\end{abstract}

Keywords---learning medium, multimedia equipment, multimedia learning, quality management, student competence.

\section{Introduction}

Vocational high schools are formal educational institutions that take part in preparing qualified human resources or high school level graduates, namely graduates who are qualified and competitive in the regional and global arena through the learning process in schools because the purpose of vocational education is to form graduates (Bahrul \& Yusuf, 2010). Middle level have specific skills in the business world and the world of work. One of the basic subjects in SMK is the basic subjects of electricity and electronics which need to be maximized properly to improve students' cognitive intelligence.

The development of the education sector is very urgent and must be implemented by the government and supported by the private sector as partners or stakeholders. The education sector is a very strategic issue, if a nation wants to take part at the global level and most importantly to build its citizens so that they are dignified and not considered backward by other countries. Law Number 20 of 2003 concerning the National Education System clearly states: that national education functions to develop its capabilities and shape the character and civilization of a nation with dignity to educate the life of the nation which aims to develop the potential of students to become human beings who believe and devote themselves to God. The One, noble, healthy, knowledgeable, competent, creative, 
independent, and a democratic and responsible citizen (Law on National Education System No. 20 of 2003, article $3)$.

Based on the above laws, it can be understood that education is a vital and very important national intelligence process. It is said to be vital because of education (Makawimbang, 2011). humans can develop all the potential that each individual has, both intellectual, emotional and spiritual potential. In other terms, in terms of cognitive, affective and physics motor aspects, it can develop through the educational process. Education can also be considered very important because, through the educational process, humans can overcome the obstacles of life, especially in the era of globalization and technology which is competitive.

Oriented to the Sikdiknas Law No. 20 of 2003 article 3 related to the objectives of national education as well as the elucidation of article 15 which states: "that vocational education is secondary education that prepares students especially to work in certain fields". This explanation has a message that every institution that provides vocational education (SMK) must be committed to making its graduates able to work in a certain field.

Standard Operating Procedure (SOP) for the implementation of vocational education (SMK) in Indonesia refers to Government Regulation No. 29 of 1990, article 3 paragraph 2, states that: The objectives of vocational secondary education prioritize the preparation of students to enter the workforce and the development of professional attitudes through letters Decree of the Minister of Education and Culture No.181 / U / 1996 which contained. (Mulyasa, E., 2015). The government has pursued policies so that honesty schools are more responsive in responding to the challenges of the labor needs needed for development".

The purpose of vocational education according to Permendikbud No. 49 of 2014 Chapter I Article 1 concerning the Indonesian National Qualification Framework (KKNI) is in addition to producing graduates who are ready to work, also producing productive, creative, innovative, affective Indonesians through strengthening attitudes and values, work skills, mastery of knowledge and responsibility. integrated. Vocational education graduates are required to have adaptive, innovative and applicable competencies in the world of work.

At the practical level (Munir, 2012; Evans \& Gibbons, 2007; Arjawa et al., 2018). Education in Indonesia still experiences various obstacles and problems, including: (1). National education with a curriculum that is made and arranged in such a way that the curriculum has been refined several times, but the curriculum has not been able to produce an Indonesian human figure with a complete personality. National education which has a mission wants to produce intelligent humans, who master the advancement of science and technology with the strength of faith and piety and noble character, but still at a normal level (2). The quality of education in Indonesia is still lagging behind other countries in the world and Asia. As reported by "The Learning Curve Pearson, Report Summary, 2014", releasing data on the ranking of education quality worldwide, and Indonesia is in the last rank of 40 countries recorded, this makes Indonesia the worst country in terms of quality of education. Meanwhile, based on the source Education at a Glance Interim Report: Update of Employment and Educational Attention Indicator, 2015 Indonesia's position is in 69th place out of 79 countries surveyed.

\section{Method}

In this study using a qualitative descriptive, which is carried out and is a reflection of theory and practice as a research application (Sugiyono, 2011). To improve learning through media between teachers and students.

- Data collection techniques that focus on the phenomenological process and meaning of an event being studied, the data collection process is carried out using three main techniques, namely observation, in-depth interviews, and documentation study.

- Participatory observation is recognized as having advantages when compared to non-participatory observation

- In-depth interviews are conducted on research based on several considerations, among which the interview method is considered to be the most effective in obtaining a clear picture.

- Documentation study as material to open insights in learning basic media of electricity and electronics to improve student competence, as well as validation of research results 


\section{Results and Discussion}

\section{Learning quality planning}

Multimedia-based learning planning to improve student competence at SMKN Cimahi City and SMKN Kota Bandung as well as the vision, mission and goals of the school to produce quality, competitive, and competitive graduates in society, is planned through school education programs and teacher learning programs respectively. subject supervisor (Pidarta, 2013; Brett, 1995; Leutner, 2014). The school program is an effort to increase and develop school resources to achieve 8 education management standards through short-term programs, medium-term programs and long-term programs, as well as enhancing and developing teacher competencies through teacher forum activities. The teacher learning program is related to the planning of teaching and learning process activities including the 2013 curriculum implementation development learning plan, the development of teaching materials, models or multimedia-based learning techniques in order to achieve student competence.

Planning for multimedia-based learning programs to improve student competence at SMKN Kota Cimahi and SMKN Kota Bandung is formulated through academic meetings at the beginning of each year and the beginning of the semester (even). The main agenda in these activities is the formulation of a new school year activity plan, evaluating needs, evaluating program achievements and finding solutions to problems from educational activities that have been implemented, both related to supporting infrastructure, learning processes, developing teacher competence, and other related agendas. with academic activities to find the right steps. The formulation of an education and learning program plan involves the principal, the supervisory deputy head, teachers, and education staff. Each principal, wakasek, department, educational staff and teachers drafted an activity plan and the results of the activity, both in relation to school development programs, plans for learning activities and plans for implementing teacher learning. The report on the results of the activities and the proposed draft are used as material in the formulation of plans for education and learning programs.

\section{Organizing the quality of learning}

Organizing multimedia-based learning to improve student competence at SMKN Cimahi City and SMKN Kota Bandung, by maximizing school resources through the main tasks and functions and authorities of each in the school organizational structure to organize learning programs and implementation of the teacher learning process Organized school resources concern human resources and infrastructure facilities because the multimedia-based learning process requires the support of various resources, both as implementers, policymakers and supporting elements through their respective main tasks and functions and authorities (Sallis, 2010; Grosseck \& Holotescu, 2010; Mayer \& Moreno, 2002). In general, SMKN Kota Cimahi and SMKN Kota Bandung have a school organizational structure, consisting of (1) Principal, (2) Deputy Principal with several fields, (3) head of department, (4) educators and education personnel, and ( 5) students.

Multimedia-based learning programs to improve student competence at SMKN Cimahi City and SMKN Kota Bandung according to the vision, mission and goals, compiled in annual programs (Prota), semester programs (Promes), teacher learning plans (Syllabus and RPP), evaluation and assessment the learning process by educators, educational units as well as by the government/collaboration with industrial institutions, as well as improvement and enrichment programs to achieve student competencies according to competency standards and the curriculum developed by the school, namely competence attitudes, knowledge and skills. Learning programs are planned through classroom learning in theory, as well as practical activities in schools and industry. To achieve student competency standards, a curriculum development team, a supervisory team and a infrastructure development team were formed.

Multimedia-based learning processes to improve student competence at SMKN Cimahi City and SMKN Kota Bandung are grouped into meeting stages designed by teachers and curriculum development teams in syllabus and lesson plans to shape student competencies in social attitudes, spiritual attitudes, knowledge and skills according to KD standards (Sanusi, 2012; Han et al., 2013; Chachil et al., 2015). KI and school KKM standards. The RPP which is designed consists of 14 meetings and 2 meetings for UTS and UAS. In general, the Principals at SMKN Cimahi City and SMKN Kota Bandung in the learning process according to the program, give authority to the wakasek in the field of curriculum and teachers, and coordinate with the wakasek in the field of infrastructure or other facilities to design concepts, methods or learning techniques, and are given responsibility. responsible for improving the learning process in order to achieve student competency standards according to the KKM set by the school. These two State Vocational High Schools determine the KKM Standard for an average student grade of 76. 


\section{Implementation of quality learning}

Implementation of multimedia-based learning to improve student competence at SMKN Cimahi City and SMKN Kota Bandung through the stages of planning the teaching and learning process, implementing the teaching and learning process, and evaluating or assessing learning outcomes. In the planning stage of the teaching and learning process, the principal coordinates with the wakasek and the head of the department to ensure readiness for the implementation of the teaching and learning process, in terms of schedules, infrastructure and teacher readiness. (Sutarman et al., 2020). Teachers who teach basic subjects of electricity and electronics at SMKN Cimahi City and SMKN Kota Bandung have appropriate educational backgrounds, infrastructure resources for multimedia-based learning, RPPs which serve as guidelines for teacher learning have been approved by the Deputy Head of the curriculum field, and the teachers have teaching materials. in the form of books, modules and other learning support materials. Planning for the teaching and learning process by identifying readiness aims to ensure that the implementation of the teaching and learning process can run as planned with the readiness of school resources, and the achievement of student competencies as expected.

The multimedia-based teaching and learning process to improve the competence of students at SMKN Kota Cimahi and SMKN Kota Bandung involves teachers, infrastructure resources, students, and teaching materials through: preliminary activities, core activities, and closing activities. The preliminary activity begins with the reading of a prayer together led by the class leader, then the teacher explains the material to be discussed. The core activity, the teacher explains the subject matter by utilizing available learning media, conducts written tests to test student understanding. The closing activity, the teacher conducts a question and answer discussion and ends with a prayer reading. In the core activities, there is a difference in the process between SMKN Cimahi City and SMKN Kota Bandung. The core activity at SMKN Cimahi City, teachers use learning media in the form of infocus to display subject matter in the form of power points and have teaching materials in the form of books from the National Education Office, but teachers at SMKN Kota Bandung still use blackboard media and do not have teaching material books. In the closing activity, Cimahi City Vocational School teachers gave additional assignments as enrichment, while teachers at Bandung City SMKN gave additional assignments due to incomplete delivery of subject matter. The difference in the multimedia-based teaching and learning process in the two SMKNs occurs because SMKN Cimahi City has the capacity to support multimedia learning media in each classroom, while the SMKN Kota Bandung is still limited (Alexander \& Hedberg, 1994; Hwang et al., 2007).

Assessment of the teaching and learning process at SMKN Kota Cimahi and SMKN Kota Bandung through tests and observations. In general, the assessment of the teaching and learning process refers to the 2013 curriculum assessment standards which include the competence of students' attitudes, knowledge and skills (Suyono \& Hariyanto, 2011). The assessment of teaching and learning processes and outcomes is carried out by educators, schools, government and industry in the form of: (1) written tests, (2) oral tests, (3) assignments, and (4) portfolios. The teacher's daily assessment concerns self-assessment, learning outcomes through oral and written tests in the form of direct tests in the teaching and learning process and through assignments. School assessments are UTS and UAS. Assessment by the government is the national exam. Meanwhile, the assessment by the industry is when students carry out field practice. Teacher assessment, UTS and UAS are the cumulative grades of student passing standards. And if the KKM standard has not been achieved, then a remedial is carried out.

\section{Evaluation of learning quality}

Multimedia-based learning evaluation to improve student competence at SMKN Cimahi City and SMKN Kota Bandung towards teachers is related to teacher performance in implementing main tasks and functions in the learning process as well as student competency outcomes (Sobahi et al., 2010). Evaluation techniques are used to assess teacher performance and academic achievement through reports on the achievement of teacher program activities in the learning process, and through academic supervision techniques. Teacher performance reports are carried out every semester for evaluation and assessment of learning program achievements, and supervision activities are carried out regularly by a team of supervisors that is formed. The evaluation and assessment techniques for basic electricity and electronics teachers at SMKN Kota Cimahi and SMKN Kota Bandung are carried out through tests and assignments. Through the test is done in daily, monthly, mid-semester and end of semester. A written test is carried out at the beginning of each lesson and an oral test at the end of the lesson in the form of a question and answer. Assignments periodically depending on needs.

The steps for evaluating multimedia-based learning programs at SMKN Cimahi City and SMKN Kota Bandung are by formulating in academic meetings to find solutions which are generally at the beginning of each year or at the 
beginning of the semester based on reports on the results of program implementation, as well as problems with the results of supervision. The steps to evaluate the multimedia-based electricity and electronics basic learning program at SMKN Cimahi City and SMKN Kota Bandung in addition to oral tests and written tests to determine the development of student abilities, assignments to enrich student knowledge and skills, and remedial to meet predetermined KKM standards school.

\section{Constraints on the implementation of learning quality}

The obstacles faced by the implementation of multimedia-based learning at the two SMKN schools are as follows:

- Teacher competence in multimedia;

- Reducing the number of learning hours;

- Difficulties of teachers in providing multimedia-based teaching materials.

What are the obstacles faced by the implementation of multimedia-based learning at SMKN Kota Bandung include: (1). Weak teacher competence in multimedia (2). Limited multimedia learning media so that it must take turns (3). Limited time with a difficult scope of subject matter (4). Teachers have difficulty in designing multimedia-based learning models (5). Lack of appropriate book teaching materials.

\section{Conclusions}

Based on the above discussion, it has shown that the two schools are SMKN. Not yet running optimally, including the following:

- Multimedia learning planning in improving student competence

- Multimedia learning organizers have not shown to improve student competence

- Implementing multimedia learning has not improved learning on student competencies

- Evaluation of multimedia learning in improving the quality of students' competency logging has not been significant

- Inhibiting factors for multimedia learning in improving student competence there are still obstacles in mastery of multimedia

\section{Implications}

- Developing a multimedia learning plan has an impact on improving student competence

- Organizing multimedia learning has an impact on improving student competence

- Implementation for carrying out multimedia learning has an impact on improving student competency learning

- Evaluation of multimedia learning in improving the quality of logging has a significant impact on student competence

- Identifying the factors inhibiting multimedia learning has an impact on increasing student competence in multi-media mastery

\section{References}

Alexander, S., \& Hedberg, J. (1994). Evaluating technology-based learning-which model. In IFIP TC3/WG3. 2 Working Conference on the Design, Implementation and Evaluation of Interactive Multimedia in University Settings (pp. 233-244). Elsevier. Chang, C. C., Liang, C., Chou, P. N., \& Lin, G. Y. (2017). Is game-based learning better in flow experience and various types of cognitive load than non-game-based learning? Perspective from multimedia and media richness. Computers in Human Behavior, 71, 218-227. https://doi.org/10.1016/j.chb.2017.01.031

Arjawa, A. G. P., Sariyasa, S., \& Suweken, G. (2018). Developing instructional multimedia for teaching line and angle to the seventh grade students of junior high school. International Research Journal of Engineering, IT and Scientific Research, 3(5), 66-75. 
Brett, P. (1995). Multimedia for listening comprehension: The design of a multimedia-based resource for developing listening skills. System, 23(1), 77-85. https://doi.org/10.1016/0346-251X(94)00054-A

Chachil, K., Engkamat, A., Sarkawi, A., \& Shuib, A. R. A. (2015). Interactive multimedia-based mobile application for learning Iban language (I-MMAPS for learning Iban language). Procedia-Social and Behavioral Sciences, 167, 267-273. https://doi.org/10.1016/j.sbspro.2014.12.673

Evans, C., \& Gibbons, N. J. (2007). The interactivity effect in multimedia learning. Computers \& Education, 49(4), 1147-1160. https://doi.org/10.1016/j.compedu.2006.01.008

Grosseck, G., \& Holotescu, C. (2010). Microblogging multimedia-based teaching methods best practices with Cirip. eu. Procedia-Social and Behavioral Sciences, 2(2), 2151-2155. https://doi.org/10.1016/j.sbspro.2010.03.297

Han, I., Eom, M., \& Shin, W. S. (2013). Multimedia case-based learning to enhance pre-service teachers' knowledge integration for teaching with technologies. Teaching and Teacher Education, 34, 122-129. https://doi.org/10.1016/j.tate.2013.03.006

Hayat, B., \& Yusuf, S. (2010). Benchmark internasional mutu pendidikan. Jakarta: Bumi Aksara.

Hwang, W. Y., Wang, C. Y., \& Sharples, M. (2007). A study of multimedia annotation of Web-based materials. Computers \& Education, 48(4), 680-699. https://doi.org/10.1016/j.compedu.2005.04.020

Leutner, D. (2014). Motivation and emotion as mediators in multimedia learning. Learning and Instruction, 29, 174175. https://doi.org/10.1016/j.learninstruc.2013.05.004

Makawimbang, J. H. (2011). Supervisi dan peningkatan mutu pendidikan.

Mayer, R. E., \& Moreno, R. (2002). Aids to computer-based multimedia learning. Learning and instruction, 12(1), 107-119. https://doi.org/10.1016/S0959-4752(01)00018-4

Munir, F., Nielsen, K., Garde, A. H., Albertsen, K., \& Carneiro, I. G. (2012). Mediating the effects of work-life conflict between transformational leadership and health-care workers' job satisfaction and psychological wellbeing. Journal of nursing management, 20(4), 512-521.

Pidarta, M., \& Kependidikan, L. (2013). stimulus ilmu pendidikan bercorak Indonesia. Jakarta: Rineka Cipta.

Sallis, E. (2010). Integrated Quality Management. Bogor: IRCiSoD Publisher

Sanusi, A. (20120). 6 Life Value System (Lecture Materials Education Facts, Policies, Philosophy Theory). Bandung: Uninus

Sobahi, K. (2010). Education Management. Bandung: Chakra.

Sugiyono, (2011). Educational Research Methods: Quantitative Approaches, Qualitative, and $R \&$ D. Bandung: Alfabeta

Sutarman, A. L. N. (2020). Manajemen Strategi Pendidikan Karakter Peserta Didik.

Suyono, H. (2011). Belajar dan pembelajaran. Bandung: Remaja Rosdakarya. 